\title{
VOLUME CHANGES IN BRICK MASONRY MATERIALS
}

\author{
By L. A. Palmer
}

\section{ABSTRACT}

Volume changes in bricks and mortars attending variations in moisture content and temperature have been studied. There were included in the study $21 \mathrm{ce-}$ ments (both Portland and masonry), 7 limes, and 8 makes of brick received from various sections of the United States. The shrinkage of mortars during hardening and the alternate expansion on wetting and shrinkage on drying occurring subsequent to bardening have been measured. Varying the moisture content produced far smaller volume changes in well-burned brick than in most of the mortars. Underburned brick expanded appreciably on wetting. It is indicated that differential volume changes between brick and mortar caused by variations in moisture content are apt to be greater than those produced by normal temperature variations. Volume changes in hardened mortars were least in the case of straight lime-sand mortars.

\section{CONTENTS}

I. Introduction 1004

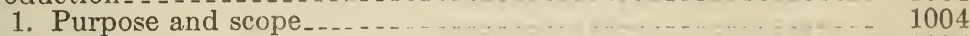

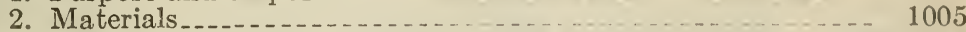

II. Test procedure $\ldots 1006$

1. Preparation of test specimens _.............. 1006

(a) Mortar specimens _... 1006

(1) Proportions of dry ingredients_......... 1006

(2) Mixing water............ 1006

(3) Methods of molding test specimens _..... 1007

(a) Specimens for the study of initial

(b) Specimens for the study of volume changes subsequent to hardening-

(4) Number of test specimens .........

(b) Brick specimens

2. Exposure of test specimens _........ 1009

(a) Mortars _....... 1009

(1) Test specimens for the study of shrinkage during hardening . . .

(2) Test specimens for the study of linear changes subsequent to hardening ........

(a) Mortars containing either masomry or Portland cement..........

(b) Mortar containing only lime and sand

(3) Changes in length due to thermal change...

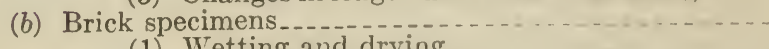

(1) Wetting and drying .................. 1010

(2) Freezing and thawing ............ 1010

(3) Thermal change ................... 1010

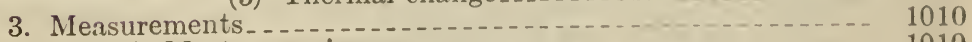

1009

1009

1009

1010

1010

1010

(1) The study of initial shrinkage hardening ............... 1010

(b) Brick specimens........... 1011 
III. Results

1. Mortars

(a) Initial shrinkage

(1) $1: 3$ mortars . .

(2) $1: 4$ mortars .................... 1012

(3) Lime and cement mortars............. 1012

(4) Water repellant materials............ 1013

(b) Effect of thermal change..................... 1013

(c) Alternate wetting and drying .............. 1014

(1) $1: 3$ mortars $\ldots \ldots$

(2) $1: 4$ mortars

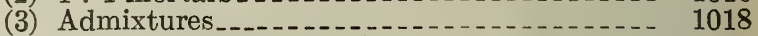

(4) Water repellant materials _.......... 1019

(a) Effect of thermal change

(b) Alternate wetting and drying

(c) Alternate freezing and thawing ........... 1023

IV. Summary and conclusions

V. Acknowledgments

\section{INTRODUCTION}

\section{PURPOSE AND SCOPE}

It is reasonable to assume that the tendency of a mortar to remain bonded under any and all conditions is greater, the smaller its volume changes, provided, of course, that the masonry unit to which it adheres undergoes little or no expansion or contraction. In other words, by reducing to the lowest possible minimum the differential volume changes in unit masonry the life of the bond should be increased. Increasing the life of the bond between mortar and units should help in part at least to reduce water penetration through the masonry.

It is obvious that a volume change of a given magnitude would be more destructive in hardened than in plastic mortar. The latter occurrence would tend to interfere with the formation of a good bond, but the former would tend to destroy the bond, thereby producing partial or complete separation of the mortar and masonry unit. In vertical joints there would be a tendency for water to enter more readily after this has happened. However, it is reasonable to suppose that water might not penetrate so easily in load-bearing joints where pressure tends to keep mortar and units in intimate contact even when there is no adhesion of the one material to the other. This is in good agreement with what one may observe during a field study. Such observations make it very apparent that most of the excessive water penctration is between the mortar and units in vertical joints.

Sabin, ${ }^{1}$ Pearson, ${ }^{2}$ Schurecht and Pole, ${ }^{3}$ Stradling, ${ }^{4}$ White, ${ }^{5}{ }^{6}$ and Davis and Troxell ${ }^{7}$ have studied volume changes in masonry materials

I. C. Sabin, Cement and Concrete, 2 d ed., p. 106; 1907. 2J. C. Pearson, Shrinkage of Portland Cement Mortars and Its Importance in Stucco Construction,
Proc. Am. Conerete Inst., 17, p. 135; 1921.

11. G. Schurecht and $G$. $R$. Pole, Effect of Water in Expanding Ceramic Bodies of Different Compositions, J. Am. Cerain. Soc., 12, No. 9, pp. 596 to 604; 1929.

R. E. Stradling, Department of Scientific and Industrial Research, Building Rescarch Bulletin No. 3, Effects of Moisturc Changes on Building Materials. 14. A. H. Wh; 1914. Volume Changes in Portland Cement and Concrete, Proc. Am. Soc. for Testing Materials,

A. I. White, Destruction of Cement Mortars and Concrete through Expansion and Contraction, roc. Am. Soc. for Testing Materials, 11, p. 531; 1911 .

${ }^{7}$ Raymond E. Davis and G. E. Troxeh, Volumetric Changes in Portland Cement Mortars and Concretes, Proc. Am. Concreto Inst., 25, pp. 210 to $260 ; 1929$. 
and emphasize either that expansion due to the taking up of moisture varies considerably among materials or that volume changes in mortars due to moisture absorption are greater than those due to thermal changes. In this work volume changes resulting from the absorption of water by brick and several types of mortars were specially studied, but attention was also given to thermal changes, including alternate freezing and thawing.

\section{MATERIALS}

One sand was used throughout in these tests. This was a fairly clean mortar sand, its screen analysis (made with United States standard sieves) being as follows:

Passed No. 8 sieve, retained on No. 20

Passed No. 20 sieve, retained on No. $30--2=--2$

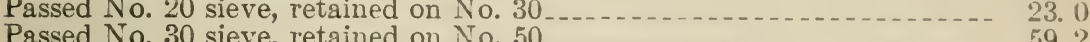

Passed No. 50 sieve, retained on No. $100 \ldots$

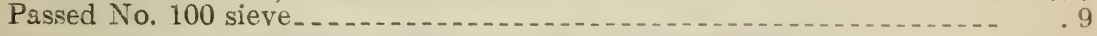

Total_...

Eleven Portland cements were included in the study. These were representative of products of manufacturers in various parts of the United States. Two of these (Nos. 2 and 11) were white Portland cements. One of them (No.5) was a quick hardening cement, this property being attributable more to fineness of particle size than to any other factor.

Seven limes were studied. Three (Nos. 1, 5, and 6) were high calcium limes. The others (Nos. 2, 3, 4, and 7) were dolomitic hydrates. No. 6 was the only quick (lump) lime used. These limes were representative of material produced in various sections of the United States.

There were 10 masonry cements. No. 1 was a mixture of hydrated lime and water-granulated blast-furnace slag. No. 2 was the same as Portland cement No. 11, but contained calcium stearate. No. 3 was a mixture of hydrated lime and Portland cement. No. 4 was a hydraulic lime. No. 5 was a Portland cement with paraffin added to give it water repellent properties. Nos. 6 and 9 were natural cements. No. 7 was a mixture of Portland cement, crushed limestone, and bentonite and No. 8 was a mixture of Portland and natural cements. No. 10 was a mixture of Portland cement and blastfurnace slag.

In the study of the effect of water-repellent substances on volume changes, calcium stearate alone was used. This substunce is an insoluble soap, and is representative of a class of materials now being rather widely used.

Eight different manufacturers' products were used in the study of volume changes of brick. Two manufacturers included brick which they considered to be distinctly underburned and not representative of their marketable product. Both face and common brick made from clay or shale were included in the study. (Table 1.) 
TABLE 1.-Kinds of brick used

\begin{tabular}{|c|c|c|c|}
\hline Brick No. & $\begin{array}{c}\text { Range of } \\
\text { total } \\
\text { absorption } \\
\text { (48 hours } \\
\text { total } \\
\text { immersion) }\end{array}$ & Molding process & Raw material \\
\hline & $\begin{array}{l}\text { Per cent } \\
11.5-17.5 \\
5.2-10.7 \\
6.0-11.5 \\
9.5-16\end{array}$ & $\begin{array}{l}\text { Dry-press. } \\
\text { Stifi-mud, side cut } \\
\text { Dry-pross. }\end{array}$ & $\begin{array}{l}\text { Mixture of surface clay and shale. } \\
\text { Shale. } \\
\text { Do. } \\
\text { Surface clay. }\end{array}$ \\
\hline 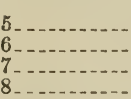 & $\begin{array}{c}4.2-9 \\
4.5-9.8 \\
18.4-25.1 \\
19.4-25.6\end{array}$ & 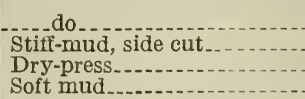 & $\begin{array}{l}\text { Fire clay. } \\
\text { Do. } \\
\text { Surface clay. } \\
\text { Do. }\end{array}$ \\
\hline
\end{tabular}

\section{TEST PROCEDURE}

\section{PREPARATION OF TEST SPECIMENS}

\section{(a) MORTAR SPECIMENS}

(1) Proportions of Dry Ingredients.-Except in the case of lime No. 6, the amounts of dry ingredients were proportioned on a volume basis. At the time of proportioning the weight as well as the volume of each dry ingredient was obtained.

The weight of the hydrated high calcium lime in the mortar composed of 1 volume of hydrated lime and 3 volumes of sand (1:3 mortars) was nearly one-seventh that of the sand for both limes. A 1:3 mortar was made from lime No. 6 (a quicklime) by using an amount such that the weight of $\mathrm{Ca}(\mathrm{OH})_{2}$ equivalent to the weight of $\mathrm{CaO}$ added was one-seventh of the weight of sand.

After having obtained data with the $1: 3$ mortars made of the cementing materials without admixtures, those cementing materials which exhibited the extreme conditions from the standpoint of volume changes subsequent to hardening of the specimens were selected for the study of admixtures and leaner mixes (1:4 mortars). Therefore in such mortars, Portland cement No. 1, masonry cement No. 10, and limes Nos. 2 and 6 were used. The proportions by volume in the mortar admixtures were: 1 lime:1 cement:6 sand, 1 lime:1 cement: 8 sand, and 2 lime: 1 cement: 9 sand.

'The weight of calcium stearate when added to the cementing materials (in the laboratory) was 2 per cent of the combined weight of cementing materials alone. Masonry cement No. 9 contained calcium stearate, which was incorporated at the factory, and its exact quantity is not known.

(2) Mixing WATER.-The amount of mixing water required to produce "standard consistency" was determined in each case prior to making the mortar specimens. The procedure followed was the "flow-table method" described in sections F3g(3)a and F3g(3)b, Federal Specification (revised) SS-C-181 for cement, masonry. The "flow" is determined by measuring the increase in diameter of a mass of mortar after removing a mold containing it on the flat, circular top of a table and dropping the table through a height of one-half inch 25 times in 25 seconds. 
(3) Methods of Molding Test Specimens-(a) Specimens for the study of initial shrinkage. - Six specimens 1 by 1 inch by 10 inches were made for each mortar in the study of changes in length during the period of hardening. 'The brass molds in which these specimens were formed were about a half-inch longer than the specimens. This half-inch difference allowed space for two glass plates, each one-fourth inch in thickness, to be cemented on the ends of the specimens. The center's of the plates were marked, and measurements were taken between the mark on one plate and that on the other

All hydrated limes were soaked in the mixing water in air-tight containers for a period of 48 hours before specimens were molded. The quicklime (lime No. 6) was soaked in this manner for two weeks.

After lubricating their inner metal surfaces the molds were put on glass plates, which were covered with waxed paper. The molds were then filled with the mortar. Tamping and troweling were aroided.

(b) Specimens for the study of volume changes subsequent to hardening.- Six specimens for each mortar were-made in steel frames (5 by 23 inches by 1 inch) resting on glass plates covered with waxed paper. In this case there were two $3 / 4$ by $3 / 4$ by $3 / 4$ inch glass plates cemented into each end of the specimens near the corners. These aftorded smooth contact points for extensometer readings and two different readings between two different pairs of contact points could be taken. After filling the frames with mortar, two 34 -inch glass rods covered with waxed paper were stuck perpendicularly through the 1 -inch thick slab of fresh mortar. The rods when so placed were 20 inches apart and each was centered at $1 \frac{1}{2}$ inches from the end of the specimen. The two metal points of a 20 -inch strain gage served to mark the positions for the glass rods.

When the mortar specimens had hardened sufficiently the glass rods were removed and brass screws were put in the holes. The head of each screw contained a countersunk hole. The points of the strain gage could be made to fit into the holes in the two screws, 20 inches apart. The screws were fixed firmly in place with a paste of lithargeglycerin cement.

(4) Number of Test Specimens.-The total number of specimens was 540 , the number of mortars, 45 . The nature of the mortars is indicated in Table 2. 
TABLE 2.-Mortars

\begin{tabular}{|c|c|c|c|}
\hline Cementing materials & Proportions by volume & $\begin{array}{l}\text { Number } \\
\text { of test } \\
\text { speci- } \\
\text { mens }\end{array}$ & Mortar No. \\
\hline $\begin{array}{l}\text { Limes } 1 \text { to } 7 \text {, inclusive } \\
\text { Portland cements } 1 \text { to } 11 \text {, inclusive } \\
\text { Masonry cements } 1 \text { to } 10 \text {, inclusive } \\
\text { Lime No. } 2\end{array}$ & 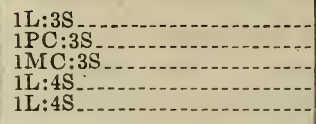 & $\begin{array}{r}84 \\
144 \\
108 \\
12 \\
12\end{array}$ & $\begin{array}{l}1 \text { to } 7 \text {, inclusive. } \\
8 \text { to } 18 \text {, inclusive. } \\
19 \text { to } 28 \text {, inclusive. } \\
29 . \\
30 .\end{array}$ \\
\hline $\begin{array}{l}\text { Portland cement No. } 1 \\
\text { Masonry cement No. } 10 \\
\text { Masonry cement No. } 1 . \\
\text { Masonry cement No. } 2 \\
\text { Lime No. } 6 \text { and Portland Cement No. 1.- }\end{array}$ & 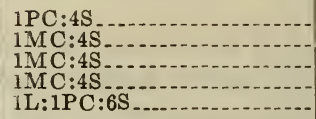 & $\begin{array}{l}12 \\
12 \\
12 \\
12 \\
12\end{array}$ & $\begin{array}{l}31 . \\
32 . \\
33 . \\
34 . \\
35 .\end{array}$ \\
\hline $\begin{array}{l}\text { Lime No. } 6 \text { and Portland cement No. } 1 \ldots \\
\text { Lime No. } 2 \text { and masonry cement No. } 10 . \\
\text { Lime No. } 2 \text { and masonry cement No. } 10 . \\
\text { Lime No. } 2 \text { and masonry cement No. } 10 . \\
\text { Portland cement No. } 1 . . .\end{array}$ & $\begin{array}{l}\text { 2L:1PC:9S } \\
1 \mathrm{~L}: 1 \mathrm{MC}: 6 \mathrm{~S} \\
1 \mathrm{~L}: 1 \mathrm{MC}: 8 \mathrm{~S} \\
2 \mathrm{~L}: 1 \mathrm{MC}: 9 \mathrm{~S} \\
1 \mathrm{PC}: 3 \mathrm{~S} \text { and calcium stear- } \\
\text { ate. } 1\end{array}$ & $\begin{array}{l}12 \\
12 \\
12 \\
12 \\
12\end{array}$ & $\begin{array}{l}37 . \\
38 . \\
39 . \\
40 . \\
41 .\end{array}$ \\
\hline Portland cement No. 1. & 1PC: $4 \mathrm{~S}$ and calcium stear- & 12 & 42. \\
\hline Masonry cement No. 10 & $1 \mathrm{MC}: 3 \mathrm{~S}$ and calcium stear- & 12 & 43. \\
\hline Lime No. 6 and Portland cement No. 1.-- & 1L:1PC: $6 \mathrm{~S}$ and calcium & 12 & 44. \\
\hline Lime No. 6 and Portland cement No. 1. & $\begin{array}{l}\text { 1L:1PC: } 8 \mathrm{~S} \text { and calcium } \\
\text { stearate. }{ }^{1}\end{array}$ & 12 & 45. \\
\hline
\end{tabular}

1 The amount of dry calcium stearate added was 2 per cent of the weight of cement or of the combined weights of lime and cement when both were used.

\section{(b) BRICK SPECIMENS}

Twenty-four bricks were selected from each of the eight makes of brick described in Table 1 . Twelve of these were taken from the hardest and 12 from the softest burned brick of the shipment. These selections were based on visual inspection and not on absorption measurements. It was proposed to observe any expansion on wetting or contraction on drying which these bricks might undergo and, hence it was necessary to start with material which had not been exposed to moisture. Absorption was, however, determined with other soft and hard burned bricks (of each shipment) similar to the ones used in the study of volume changes. The total absorptions, expressed in per cent of initial dry weights for each make of brick have been given in Table 1. In obtaining these values, the bricks were dried at about $150^{\circ} \mathrm{C}$. to constant weight and were then immersed in water at room temperature for 48 hours.

Three bricks were used to form a specimen. After drying at $150^{\circ}$ C. to constant weight (very little moisture was found to be present), the ends of the brick were roughened and joined together with a paste of litharge-glycerin cement. This was done with the bricks lying flat side down on level boards. While the cement was plastic, bench rlamps served to squeeze the ends of the bricks tightly together and reduce the thickness of the joint. The combined thickness of the two joints in a specimen was about one-eighth inch. Any shrinkage or expansion in the cementing material could, therefore, introduce only a very small error. Holes 20 inches apart were then drilled in the end bricks. Screws with heads drilled and countersunk were cemented into these holes with the litharge cement. 


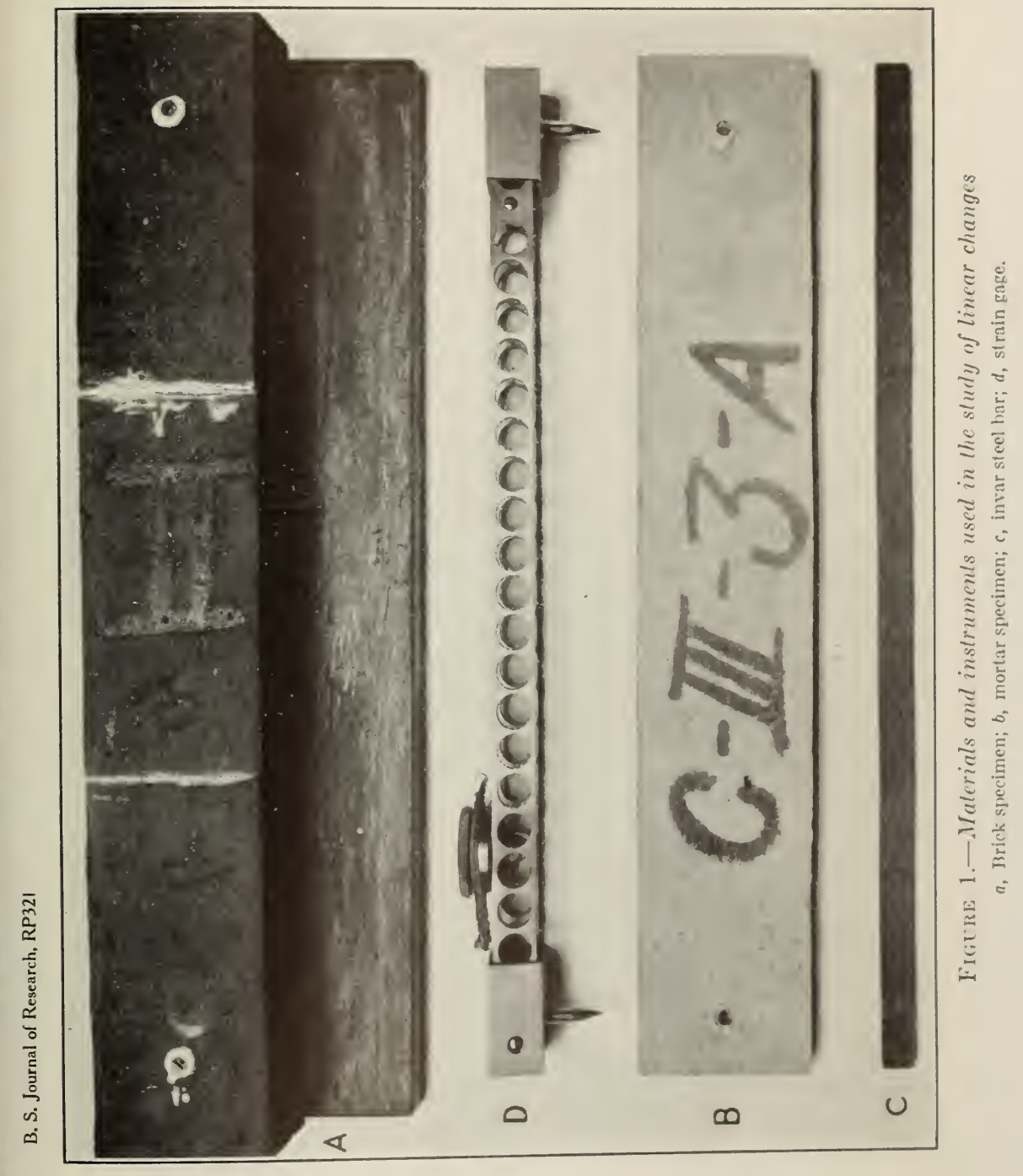


In Figure 1, $a$ is a brick specimen, $b$ is a 1 by 5 by 23 inch mortar specimen, $c$ is the standard invar steel bar for reference, and $d$ is the 20-inch Whittemore type strain gage. Four specimens were made with the soft and four with the hard burned bricks with each of the eight types of brick. Two specimens were used in the study of volume changes produced by wetting and drying and two were reserved for the study both of thermal change (on the dry specimens) and freezing and thawing of moisture-saturated specimens.

\section{EXPOSURE OF TEST SPECIMENS}

(a) MORTARS

(1) Test Specimens for the Studi of Shrinkage During HARDENING.-The specimens were removed as soon as made to a room wherein the relative humidity was $60 \pm 5$ per cent and the temperature was $21 \pm 2^{\circ} \mathrm{C}$. They remained here for a period of 10 days. The lengths of the specimens were measured at the end of 48 hours and 10 days.

(2) Test Specimens for the Study of Linear Changes SubseQUENT to HaRdening.-(a) Mortars containing either masonry or Portland cement.-Test specimens containing cement (that is, either straight Portland or masonry cement mortars or admixtures of lime and cement) were stored under water (frequently changed) when 48 hours old. They remained so immersed for 3 months, when they were removed and placed on edge in front of an elcctric fan to remore the bulk of the water. When this was accomplished the specimens were placed flat side down on dry sand in metal trays. The trays and specimens were placed in a drying oven, the temperature of which was maintained at $38^{\circ} \mathrm{C}$. and seldom varied more than $12^{\circ} \mathrm{C}$. A metal tray containing granulated calcium chloride was placed in the bottom of the oven. An electric fan within the oven operated continuously and served to keep the relative humidity uniform throughout. It seldom exceeded 25 per cent. Usually itranged from 20 to 25 per cent.

The specimens were removed from the oven when it was noted that during the course of a week there was no change in length of a specimen greater than 0.0004 of an inch. The specimens were then returned to the laboratory and put in water where they were kept for another three months. They were then remored and again dried to "constant length" in the oven and returned again to water.

(b) Mortars containing only lime and sand.-The specimens (1 inch by 5 by 23 inches) containing lime and sand alone were quite fragils during the first week or 10 days after they were formed. For this reason no attempt was made to handle them during the first 10 days, after which the brass screws for gage readings were fastened in the specimens. They then remained on glass plates for three months, exposed to the air of the laboratory. The average relative humidity of the laboratory during a year was between 35 and 50 per cent, and varied from 18 to 80 per cent. The temperature varied from $15^{\circ}$ to $32^{\circ} \mathrm{C}$., the average being about $19^{\circ} \mathrm{C}$.

After three months' storage in the laboratory, the lime-mortar specimens were taken to a room wherein the relative humidity was approximately 95 per cent and the temperature was $21^{\circ} \pm 1^{\circ} \mathrm{C}$., and for three months were daily sprinkled. At the end of this period, they were dried first in the air of the laboratory, using a fan to cir- 
culate the air rapidly about them. When the bulk of moisture had been removed in this way, the specimens were dried at $38^{\circ} \mathrm{C}$. in the constant-temperature oven for a period of time such that during a week the change in length was not greater than 0.0004 inch.

After drying, the specimens were placed in metal trays and kept about half submerged in water. Complete immersion was impracticable, for in this case the specimens became soft. Care was taken to keep the water level fairly constant. Water rose by capillarity and kept the lime-mortar specimens saturated. At the same time, the hardening process could take place to some extent at least. After soaking in this manner for three months the specimens were again dried to "constant length."

(3) Changes in Length Due to Thermal Change.-After one of the oven dryings, three of the six specimens were left for one day in the laboratory, gage readings were taken, and the specimens were then placed in a freezing room, the temperature of which ranged from $-12^{\circ}$ to $-5^{\circ} \mathrm{C}$. They remained here for at least 12 hours and linear measurements were again made. If the data for each of the specimens were not in fairly good agreement, the entire procedure was repeated until results checked reasonably well. The temperature difference between the laboratory and freezing room varied from $28^{\circ}$ to $36^{\circ} \mathrm{C}$.

\section{(b) BRICK SPECIMENS}

(1) Wetting and Drying.-The lengths of the brick specimens were first determined when dry and again after a month in water at room temperature. The specimens were then dried for a week at $150^{\circ} \mathrm{C}$., removed, cooled to room temperature, and again measured. This procedure was then repeated once.

(2) Frenzing and Thawing.-The dry brick specimens were immersed for 48 hours in water at room temperature, removed to the freezing chamber for 18 hours, and then thawed under water at room temperature for six hours. The freezing and thawing was continued until the specimens showed disintegration or had endured 20 cycles. After freezing and thawing, the specimens were dried at $150^{\circ}$ C. for a period of one week. Gage readings were taken before putting the dry specimens in water, after 48 hours' soaking, after each freezing, after each thawing, and after the oven-dried specimens had cooled.

(3) Thiminal Cuange.- The specimens were kept dry throughout these tests. 'They were removed from the laboratory to the freezing room, where they remained for at least 12 hours. They were then returned to the laboratory and the cycle was repeated several times. The laboratory and freezing room temperatures were recorded at the time strain gage readings were taken.

\section{MEASUREMENTS}

\section{(a) MORTAR SPECIMENS}

(1) The Study of Initial Shrinkage.-Measurements with micrometer calipers reading to 0.001 inch were made at the end of 48 hours and again at the end of 10 days' storage in the constant temperature-constant humidity room.

(2) The Study of Linear Changes Subsequent to HardenING.-During the three months storage in water, linear changes were 
measured from time to time. No reading was taken on the specimens until the water in which they were immersed had been at about $25^{\circ} \mathrm{C}$. for at least one hour. By carefully mixing hot and cold water, the temperature could be maintained at very approximately $25^{\circ} \mathrm{C}$.

Extensometer readings in addition to strain-gage readings were taken on the last day of each successive exposure (wetting and drying). Strain-gage readings were taken frequently during these procedures. The strain gage and extensometer were each equipped with dials reading to 0.0001 inch. The former was checked from time to time with an Anderson screw, a device for dial calibration.

A strain-gage reading could be taken within a few seconds time and specimens removed from the drying oven (temperature $38^{\circ} \mathrm{C}$.) did not cool appreciably while being measured. The readings at $38^{\circ} \mathrm{C}$. were computed to values that would have been obtained had the specimens been cooled to $25^{\circ} \mathrm{C}$. These computations were based on data obtained from the study of the effect of thermal change on the linear expansion and contraction of the specimens. These temperature corrections for the different mortars were relatively small in all cases.

A temperature correction was also made when lime mortar specimens were measured during their initial three months' storage in the laboratory. This was done whenever laboratory temperature differed from $25^{\circ} \mathrm{C}$. by an amount greater than $3^{\circ} \mathrm{C}$.

\section{(b) BRICK SPECIMENS}

The procedure followed in measuring the linear changes in the brick specimens was, in so far as the tests were similar, the same as that described for mortars.

\section{RESULTS}

\section{MORTARS}

(a) INITIAL SHRINKAGE

(1) 1:3 Mortars.-The shrinkages of the various 1:3 mortars are given in Table 3 . These data include values obtained at the end of 48 hours and 10 days for all $1: 3$ mortars. Shrinkage is expressed in terms of per cent change in length.

The data of Table 3 indicate a relatively wide variation in the initial shrinkages among the different masonry cements. Thero was not such a wide variation when the various lime and Portland cement mortars are considered.

It may be noted that the amount of shrinkage of the lime specimens at the end of 48 hours was from 75 (lime No. 4) to 86 per cent (lime No. 6) of the total shrinkage during the 10-day period. After 10 days, the lime-mortar specimens were apparently not as hard as were the Portland cement mortars when 48 hours old. The linear shrinkages of the cement mortars were more nearly completed at the end of 48 hours.

$55946^{\circ}-31-7$ 
TABLE 3.-Shrinkage of 1:9 mortars during early hardening

(Arerages for six specimens. The maximum deriation from any average value, considering all mortars, Was approximately 15 per cent)

\begin{tabular}{|c|c|c|c|}
\hline \multirow{2}{*}{ Class of mortars } & \multirow{2}{*}{ Cementing material } & \multicolumn{2}{|c|}{$\begin{array}{l}\text { Decrease in initial } \\
\text { length- }\end{array}$} \\
\hline & & $\begin{array}{l}\text { During } \\
48 \text { hours }\end{array}$ & $\begin{array}{l}\text { During } \\
10 \text { days }\end{array}$ \\
\hline 1 lime: 3 sand...... & 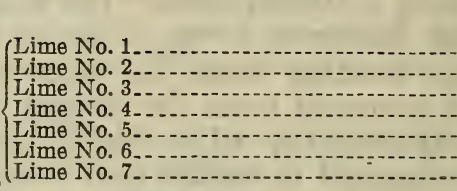 & $\begin{array}{r}\text { Per cent } \\
0.41 \\
.49 \\
.30 \\
.38 \\
.49 \\
.55 \\
.45\end{array}$ & $\begin{array}{r}\text { Per cent } \\
0.49 \\
.60 \\
.37 \\
.51 \\
.59 \\
.64 \\
.58\end{array}$ \\
\hline 1 P. C.: 3 sand... & 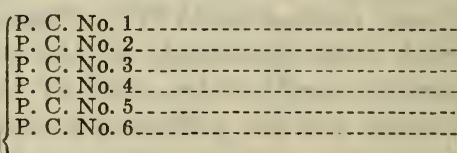 & $\begin{array}{l}.22 \\
.15 \\
.12 \\
.17 \\
.13 \\
.13\end{array}$ & $\begin{array}{r}.23 \\
: 17 \\
: 14 \\
: 19 \\
: 16 \\
.15\end{array}$ \\
\hline & $\begin{array}{l}\text { P. C. No. } 7 \\
\text { P. C. No. 8 } \\
\text { P. C. No. 9 } \\
\text { P. C. No. 10- No. } 11 \\
\text { P. C. No }\end{array}$ & $\begin{array}{l}14 \\
.14 \\
.27 \\
.11 \\
.19\end{array}$ & $\begin{array}{l}.15 \\
.15 \\
.30 \\
.11 \\
.21\end{array}$ \\
\hline \multirow{2}{*}{1 M. C.: 3 sand... } & 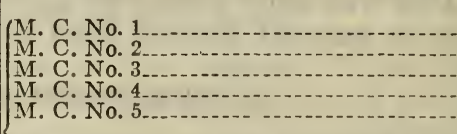 & $\begin{array}{l}.24 \\
.20 \\
.31 \\
.61 \\
.19\end{array}$ & $\begin{array}{l}.29 \\
.22 \\
.35 \\
.68 \\
.21\end{array}$ \\
\hline & $\begin{array}{l}\text { M. C. No. } 6 \\
\text { M. C. No. } 7 \\
\text { M. C. No. 8 } \\
\text { M. C. No. } 9 \text { M. C. No. } 10 \\
\text { M. }\end{array}$ & $\begin{array}{l}.33 \\
.39 \\
.40 \\
.99 \\
.26\end{array}$ & $\begin{array}{r}.37 \\
.43 \\
.44 \\
1.11 \\
.30\end{array}$ \\
\hline
\end{tabular}

The variations of shrinkage during early hardening produced by changing the relative proportions by volume of cementing materials and sand are illustrated in Figure 2. The various points in this diagram represent average values as obtained with the six specimens of each mortar. The numbers at these points designate the mortars as listed in Table 2. Figure 2 also shows the effect of calcium stearate on the early shrinkage of a few representative mortars.

The lengths of the vertical lines above and below each point represent the maximum positive and negative deviations from the average shrinkage of the six individual specimens of each mortar.

(2) 1:4 Mortars.-The "best" and the "poorest" cements (Portland cement No. 1 and masonry cement No. 10, respectively) and limes (Nos. 6 and 2, respectively) were selected on the basis of volume changes occurring subsequent to hardening. The initial shrinkages of the $1: 3$ as compared with the $1: 4$ mortars made with these materials may be noted in Figure 2.

The initial shrinkage in the $1: 4$ was less than that in the $1: 3$ mortars in all cases. This difference was greater in the masonry and Portland cement than it was in the lime mortars.

(3) Lime and Cement Mortars.-Mortar Nos. 37 and 40 were richer in lime than Nos. 35 and 38, respectively (fig. 2), and it is seen that the shrinkage during early hardening increases with the lime content. Mortars 36 and 39 were $1: 1: 8$ mortars, lean both in lime 
and cement. Their initial shrinkages were lower than those of the 1:1:6 mortars (Nos. 35 and 38).

(4) Water Repellent Materials.-The eflect on initial shrinkage produced by adding water repellent substances was not given much attention in this investigation. The subject has been studied by others ${ }^{9}$ and the results indicate that the effect in so far as the magnitude of the volume changes is concerned is very small.

Mortar No. 18 (fig. 2) was made from Portland cement No. 11 containing no water-repellent substance. Mortar No. 20 was made from masonry cement No. 2 and contained calcium stearate added

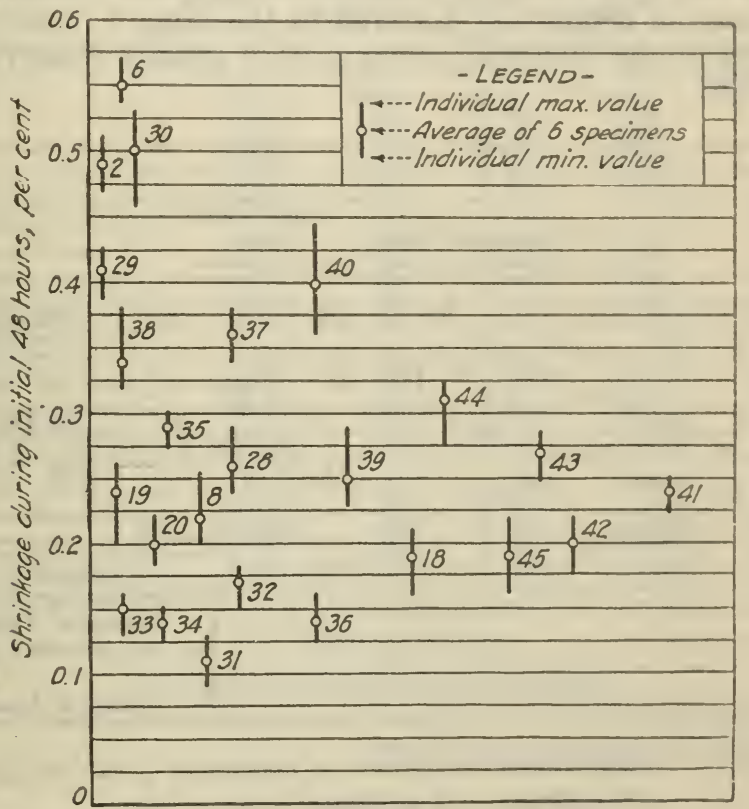

FIGURE 2.-Linear shrinkage of mortars during early hardening

at the same factory (amount not determined) where Portland cement No. 11 was produced. The initial shrinkages of these two mortars were very nearly the same. Mortar Nos. 41, 42, 43, 44, and 45 (fig. 2) containing calcium stearate may be compared with mortar Nos. 8, $31,28,35$, and 36 , respectively. The former contained calcium stearate, whereas the latter did not. In this case, the stearate was added to the cementing materials in the laboratory. The differences are not appreciable.

\section{(b) EFFECT OF THERMAL CHANGE}

The linear changes produced by subjecting dry mortar specimens to changes in temperature may be seen in Figure 3. As in Figure 2, the points in Figure 3 represent averages (in this case the average is for three specimens) and the maximum deviation in each case is represented by the length of the vertical line which extends upward

- See footnote 7, p. 1004. 
or downward from the point to show the direction of departure. The numbers in Figure 3 designate the mortars listed in Table 2.

$C$, the linear thermal coefficient, is equal to $\frac{\Delta L}{L \Delta t}$ where $\Delta L$ is the change in length of $L$ during a change in temperature of $\Delta t^{\circ} \mathrm{C}$. In Figure 3 , the values of $C$ are multiplied by $(10)^{5}$ The thermal coefficients of the 1:3 Portland cement mortars were as a whole slightly higher than those of the 1:3 lime or masonry cement mortars. This may have been due to the fact that the actual mass of cementing material in the 1:3 Portland cement mortars was relatively greater than the mass of cementing material in the other 1:3 mortars, since the densities of the Portland cements were usually relatively greater in most cases.

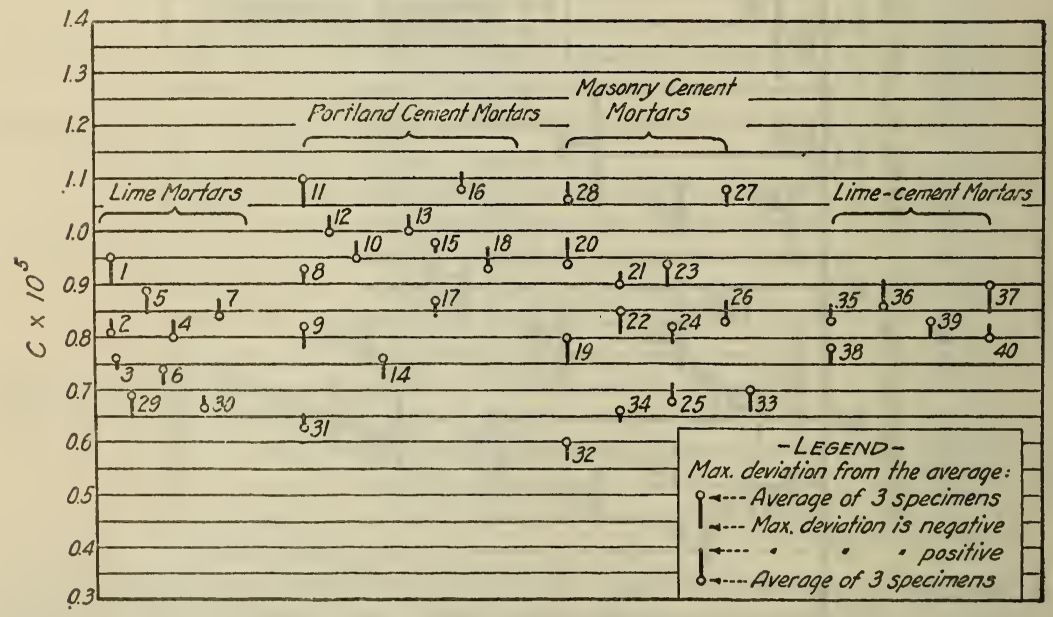

FIGURE 3.- Linear thermal coefficients of expansion of various mortars The coefficients, C, is multiplied by $10^{5}$ in the sales.

In Figure 3, Nos. 29, 30, 31, 32, 33, and 34 represent the thermal coefficients of the $1: 4$ mortars, and it may be noted these are among the lowest values obtained.

\section{(c) ALTERNATE WETTING AND DRYING}

(1) 1:3 Mortars.-The linear changes of the 1:3 mortar specimens, produced by varying the moisture content, appear in Table 4. All values in the second column are with reference to the last readings taken immediately prior to beginning the first exposure. All values in the third column are with reference to the last readings taken on the last day of the first exposure, etc. For example, after the six specimens of Portland cement No. 6 had been in water for three months they were (on the average) 0.009 per cent longer than they were a few minutes before they were first immersed in water. After the first drying (third column) they were 0.095 per cent shorter than they were when removed from water for the first time, etc. 
TABLE 4.-Linear changes in 1: 3 hardened mortar specimens subjected to alternate wetting and drying

[+ denotes expansion, - denotes shrinkage. Values are averages of results obtained with 6 specimens. The maximum deviation from any average value, considering all mortars, was approximately 10 per ceut.]

\section{1:3 PORTLAND AND MASONRY CEMENT MORTARS}

(Tests begun when specimens were $4 \mathrm{~S}$ hours old)

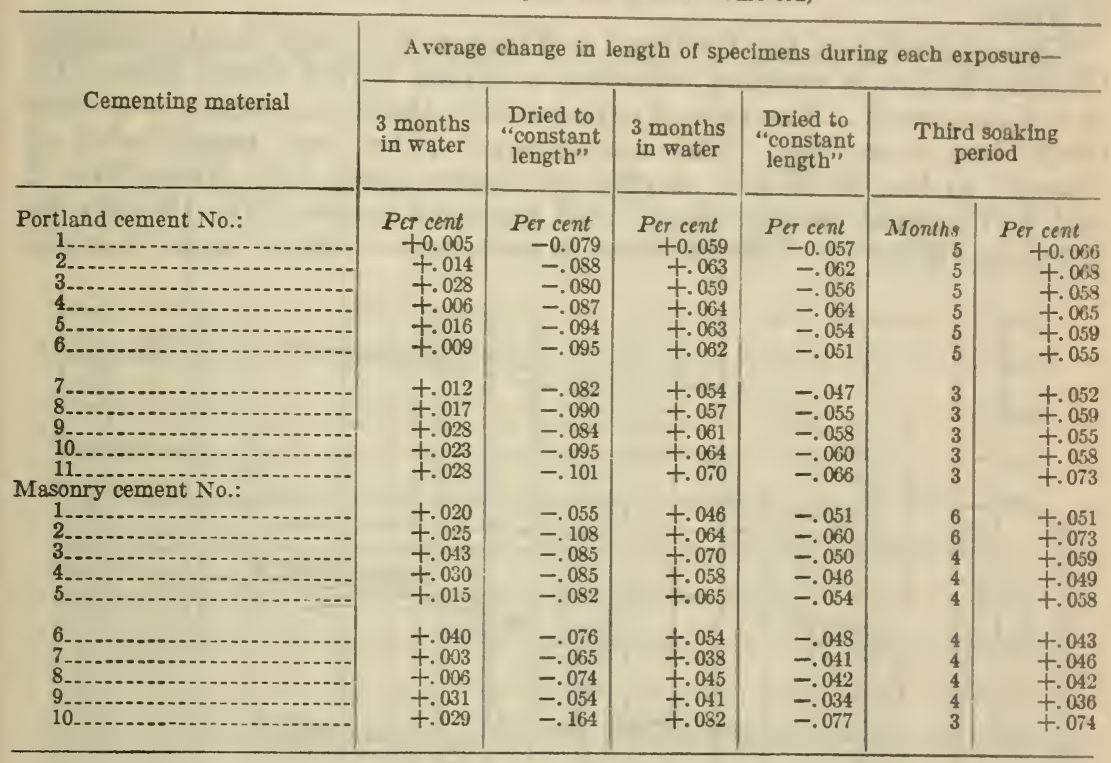

1:3 LIME MORTARS

(Tests begun when specimens were 10 days old)

\begin{tabular}{|c|c|c|c|c|c|}
\hline \multirow[b]{2}{*}{ Cementing material } & \multicolumn{5}{|c|}{$\begin{array}{c}\text { Average change in length of specimens during } \\
\text { each exposure- }\end{array}$} \\
\hline & $\begin{array}{c}3 \text { months } \\
\text { in air } \\
\text { (laboratory) }\end{array}$ & $\begin{array}{l}3 \text { months } \\
\text { in humid } \\
\text { room, } \\
\text { sprayed } \\
\text { daily }\end{array}$ & $\begin{array}{l}\text { Dried to } \\
\text { "constant } \\
\text { length" }\end{array}$ & $\begin{array}{l}3 \text { months } \\
\text { partially } \\
\text { immersed } \\
\text { in water }\end{array}$ & $\begin{array}{l}\text { Dried to } \\
\text { "constant } \\
\text { length" }\end{array}$ \\
\hline $\begin{array}{l}\text { Lime No.: } \\
1\end{array}$ & $\begin{array}{r}\text { Per cent } \\
+0.008 \\
+.002 \\
+.008 \\
+.003 \\
+.004 \\
\text { No change. } \\
-.004\end{array}$ & $\begin{array}{l}\text { Per cent } \\
+0.027 \\
+.071 \\
+.021 \\
+.036 \\
+.014 \\
+.008 \\
+.022\end{array}$ & $\begin{array}{r}\text { Per cent } \\
+0.004 \\
-.004 \\
-.017 \\
-.002 \\
-.004 \\
1-.001 \\
-.007\end{array}$ & $\begin{array}{l}\text { Per cent } \\
+0.003 \\
+.019 \\
+.011 \\
+.003 \\
+.002 \\
+.002 \\
1+.001\end{array}$ & $\begin{array}{r}\text { Per cent } \\
\text { No change. } \\
+0.004 \\
+.006 \\
-.002 \\
-.004 \\
-.004 \\
+.003\end{array}$ \\
\hline
\end{tabular}

1 A bout the magnitude of the probable error in measurement.

It is noted that the volume changes in the $1: 3$ lime mortars were generally appreciably less than those characteristic of masonry and Portland cement mortars under very similar conditions.

The alternate shrinkages on drying and expansion on wetting the cement mortars are comparable to data obtained by others. It is interesting to note that the general tendency of the lime mortars was to expand even under drying conditions in some instances. Thus, 
there was no shrinkage whatever in lime No. 1 mortar. During the entire period of test (approximately one year) lime No. 1 specimens expanded 0.042 per cent. The net volume change obtained with mortar specimens made from lime No. 6 was an expansion of 0.005 per cent. This was less than one-tenth of the expansion of the various Portland cement mortars during three months' immersion in water.

The expansion of the Portland and masonry cement mortars during the first 24 hours' soaking following a drying period varied from 0.02 to 0.05 per cent. The rate of expansion of the lime mortars was very much less than this. The comparative rates and magnitudes of changes in length of 1:3 mortar specimens made from limes Nos. 2 and 6, Portland cement No. 1 and masonry cement No. 10 may be noted in Figure 4. The full lines in each curve denote linear changes

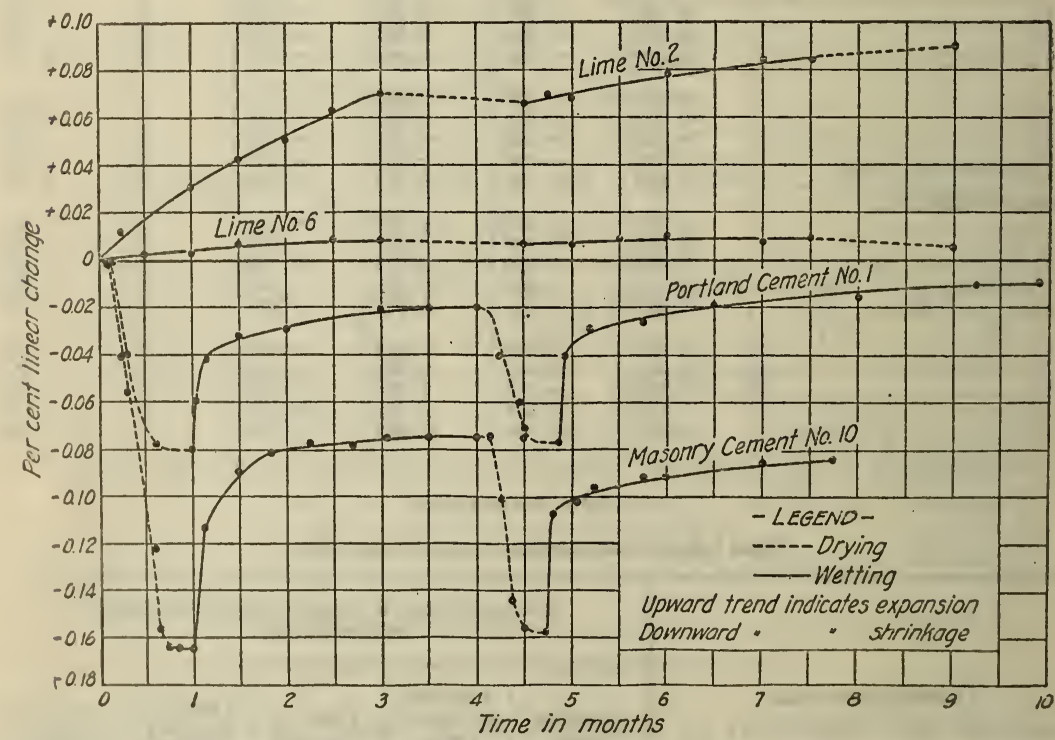

FrguRE 4.-Linear changes in hardened mortar specrmens

Tests begun when specimens were three months old.

during wetting and the broken lines denote such changes during the drying periods. The origin is the average of the readings of the six specimens of each mortar taken at the beginning of the second exposure (column 3, Table 4); that is, the specimens at this point (the origin) were three months old. The $1: 3$ lime mortars were kept saturated during the second exposure, whereas the 1:3 Portland cement mortars were dried to "constant length." The drying procedure was not continued over any definite period of time. Drying was discontinued where during a period of one week the linear change in a specimen did not exceed 0.0004 inch per 20 inches.

(2) 1:4 MORTARs.- - Linear changes produced by alternately wetting and drying the 1:4 mortars are presented in Table 5. A comparison of the data in this table with the data in Table 4 for the same cementing materials indicates that with the possible exception of lime No.6, 
the magnitude of shrinkage on drying and expansion on wetting was less in the $1: 4$ than in the $1: 3$ mortars. The difference, although appreciable, hardly warrants a preference of the $1: 4$ mortars from this standpoint alone. The mason usually experiences more difficulty in troweling the leaner mixes, and this fact must also be considered. The linear expansion and shrinkage both in $1: 3$ and $1: 4$ mortars made with lime No. 6 were relatively small. The fact that the linear changes were slightly higher in the latter case may not, therefore be significant.

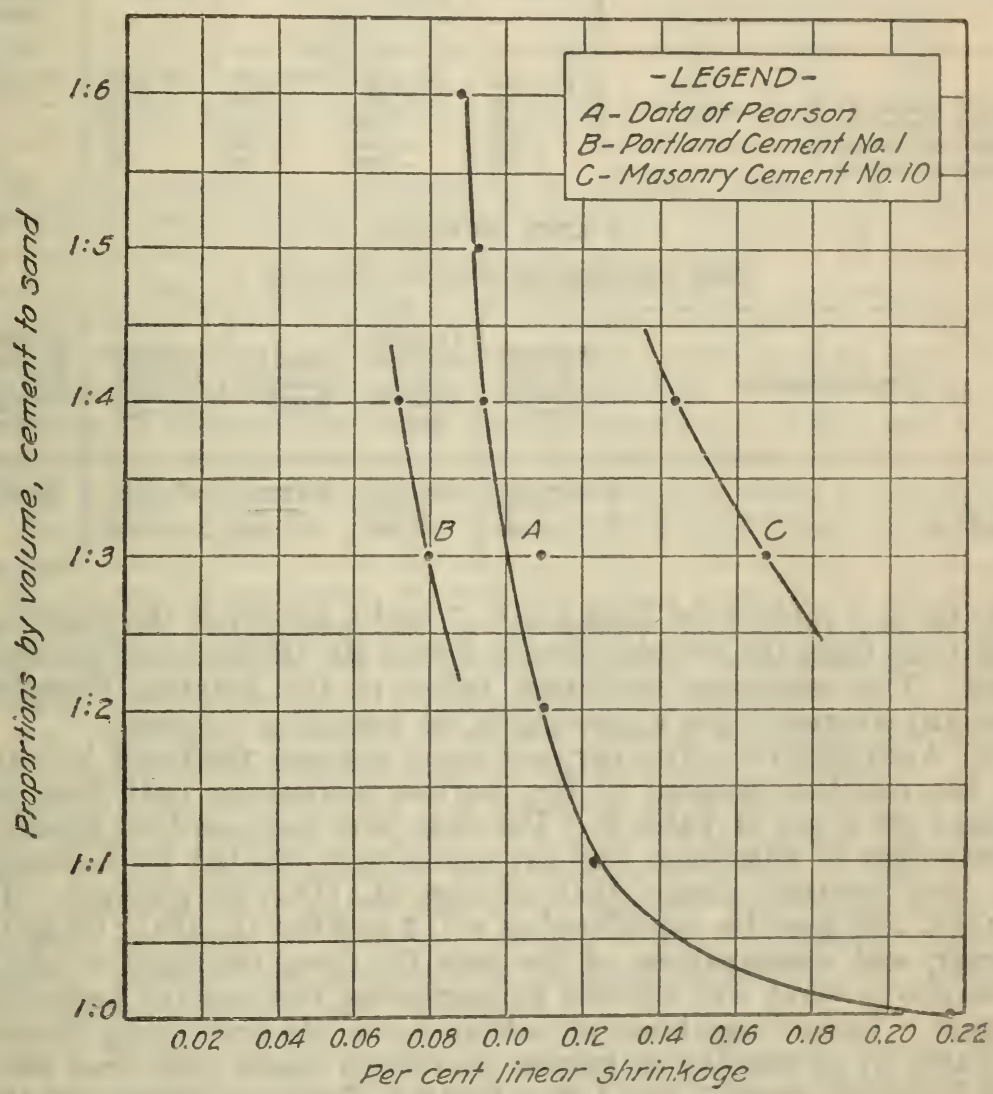

FIGURE 5.-Variations in linear shrinkage produced by changing the relative proportions by volume of cement and sand

Curve $A$ of Figure 5 is obtained by plotting the data of Pearson. ${ }^{10}$ The small portions of curves $\mathrm{B}$ and $\mathrm{C}$ are obtained by plotting the data relative to Portland cement No. 1 and masonry cement No. 10 (third column, Tables 4 and 5). The curve obtained by plotting Pearson's data indicates a sharp decrease in the cffect of leanness on linear shrinkage above the point designating $1: 1$ mortar.

10 See footnote 2, p. 1004. 
TABLE 5.-Linear changes produced by alternately wetting and drying 1:4 mortars subsequent to hardening

[A verages of 6 specimens; + denotes expansion, - denotes shrinkage]

1:4 PORTLAND AND MASONRY CEMENT MORTARS

(Tests begun when specimens were 48 hours old)

\begin{tabular}{|c|c|c|c|c|c|}
\hline Cementing material & $\begin{array}{l}3 \text { months } \\
\text { in water }\end{array}$ & $\begin{array}{l}\text { Dried to } \\
\text { "constant } \\
\text { length" }\end{array}$ & $\begin{array}{l}3 \text { months } \\
\text { in water }\end{array}$ & $\begin{array}{l}\text { Dried to } \\
\text { "constant } \\
\text { length" }\end{array}$ & $\begin{array}{l}\text { Maximum } \\
\text { deviation } \\
\text { from any } \\
\text { average } \\
\text { value }\end{array}$ \\
\hline $\begin{array}{l}\text { Portland cement No. } 1 \\
\text { Masonry cement No. } 10 \\
\text { Masonry cement No. } 1 \text {. } \\
\text { Masonry cement No. } 2 .\end{array}$ & $\begin{array}{l}\text { Per cent } \\
+0.009 \\
+.007 \\
+.024 \\
+.012\end{array}$ & $\begin{array}{r}\text { Per cent } \\
-0.071 \\
=.145 \\
=.035 \\
-.090\end{array}$ & $\begin{array}{l}\text { Per cent } \\
\quad+0.042 \\
\quad+.080 \\
\quad+.026 \\
\quad+.051\end{array}$ & $\begin{array}{r}\text { Per cent } \\
-0.040 \\
-.078 \\
-.021 \\
-.047\end{array}$ & $\begin{array}{r}\text { Per cent } \\
6 \\
14 \\
10 \\
12\end{array}$ \\
\hline
\end{tabular}

1:4 LIME MORTARS

(Tests begun when specimens were 10 days old)

\begin{tabular}{l|r|r|r|r|r}
\hline Cementing material & $\begin{array}{r}3 \text { months } \\
\text { in air } \\
\text { labora- } \\
\text { tory) }\end{array}$ & $\begin{array}{r}3 \text { months } \\
\text { in humid } \\
\text { room, } \\
\text { sprayed } \\
\text { daily }\end{array}$ & $\begin{array}{c}\text { Dried to } \\
\text { "constant } \\
\text { length" }\end{array}$ & $\begin{array}{r}3 \text { months } \\
\text { partially } \\
\text { immersed } \\
\text { in water }\end{array}$ & $\begin{array}{r}\text { Maximum } \\
\text { deviation } \\
\text { from any } \\
\text { average } \\
\text { value }\end{array}$ \\
\hline Lime No. & $\begin{array}{r}\text { Per cent } \\
-0.002 \\
-.010\end{array}$ & $\begin{array}{r}\text { Per cent } \\
+0.040 \\
+.011\end{array}$ & $\begin{array}{r}\text { Per cent } \\
-0.005 \\
-.002\end{array}$ & $\begin{array}{r}\text { Per cent } \\
+0.019 \\
\text { No change. }\end{array}$ & $\begin{array}{r}\text { Per cent } \\
20 \\
8\end{array}$ \\
\hline
\end{tabular}

In the last columns of Tables $5,6,7$, and 8 are given the maximum deviations from the average obtained with six different mortar specimens. The maximum deviation refers to the greatest departure from any average value appearing in the preceding columns.

(3) Admixtures. - The per cent linear changes produced by varying the moisture content of the mortars containing both lime and cement are given in Table 6 . The data here indicate that generally a reduction in shrinkage and expansion was effected by increasing the lime content above that of the $1 \mathrm{~L}: 1 \mathrm{PC}: 6 \mathrm{~S}$ mortars. The $1 \mathrm{~L}: 1 \mathrm{PC}: 8 \mathrm{~S}$ may be considered as a $1: 4$ and the $1 \mathrm{~L}: 1 \mathrm{PC}: 6 \mathrm{~S}$ as $1: 3$ mortar, and a comparison of the data for these two mortar admixtures shows what was effected by increasing the relative proportion of sand. The average linear shrinkage during the first drying (column 5 , Table 6) of the 1:1:6 mortar specimens made with lime No. 6 and Portland cement No. 1 was greater (Table 4, column 3) than that of the 1:3 Portland cement No. 1 mortar specimens. From the data of Tables 4 and 6 it is seen that the reverse was true in the case of lime No. 2 and masonry cement No. 10. 
TABLE 6.-Linear changes produced by alternately wetting and drying mortars containing both lime and cement

ITests begun when specimens were 48 hours old (average values for 6 specimens; + denotes expanslon; - denotes shrinkage)]

\begin{tabular}{|c|c|c|c|c|c|c|c|}
\hline Lime & Cement & $\begin{array}{l}\text { Proportions by } \\
\text { volume }\end{array}$ & $\begin{array}{l}3 \text { months } \\
\text { in water }\end{array}$ & $\begin{array}{l}\text { Dried } \\
\text { to "con- } \\
\text { stant } \\
\text { length" }\end{array}$ & $\begin{array}{l}3 \text { months } \\
\text { in water }\end{array}$ & $\begin{array}{l}\text { Dried } \\
\text { to "con- } \\
\text { stant } \\
\text { length" }\end{array}$ & $\begin{array}{l}\text { Maxl- } \\
\text { muin } \\
\text { deviation } \\
\text { from any } \\
\text { average } \\
\text { value }\end{array}$ \\
\hline $\begin{array}{l}\text { No. } 6 \\
\text { No. } 2 \\
\text { No. } 6 \\
\text { No. } 2 \ldots \ldots\end{array}$ & $\begin{array}{l}\text { PC No. } 1 \\
\text { MC No. } 10 \\
\text { PC No. } 1 \\
\text { MC No. } 10\end{array}$ & 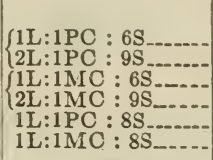 & $\begin{array}{r}\text { Per cent } \\
+0.007 \\
+.018 \\
+.015 \\
+.013 \\
+.008 \\
+.007\end{array}$ & $\begin{array}{r}\text { Per cent } \\
-0.111 \\
-.069 \\
-.126 \\
-.072 \\
-.068 \\
-.085\end{array}$ & $\begin{array}{l}\text { Per cent } \\
+0.050 \\
+.042 \\
+.049 \\
+.034 \\
+.042 \\
+.045\end{array}$ & $\begin{array}{r}\text { Per cent } \\
-0.043 \\
-.032 \\
-.046 \\
-.031 \\
-.041 \\
-.037\end{array}$ & $\begin{array}{r}\text { Per cent } \\
8 \\
10 \\
6 \\
15 \\
7 \\
12\end{array}$ \\
\hline
\end{tabular}

On the contrary the expansions on wetting (column 6, Table 6) and shrinkages on drying (column 7 , Table 6 ) of the $1: 1: 6$ and $2: 1: 9$ mortars subsequent to the first drying were smaller in all cases than the linear changes attending such exposures of the $1: 3$ cement mortars (columns 4 and 5, Table 4). A possible explanation is that the rate of initial shrinkage of the lime-cement mortars may have been less than that of the cement (no lime) mortars. If this is true, the shrinkage was probably more nearly completed at the end of 48 hours in the cement mortars than in the cement-lime mortars. Then during a later period, when conditions were favorable, the shrinkage of the latter would be greater than that of the former, which was the case.

(4) Water-Repellent Materials. - The mortars to which calcium stearate was added in the laboratory, and $1: 3$ mortars made with masonry cement No. 2 , did not differ in volume change during wetting and drying from the same mortars without the stearate. It was indicated, however, that the rate of shrinkage on drying and expansion on wetting was to some extent diminished by the presence of calcium stearate. If the data of Table 7 are compared with those of Tables 4,5 , and 6 , it will be observed that the magnitudes of the linear changes with calcium stearate (Table 7) are comparable with those of the same mortars without this waterrepellent substance. Masonry cement No. 2 contained calcium stearate, added at the factory, and Portland cement No. 11 (made at the same factory) did not. (Table 4.)

TABLE 7.-Linear changes produced by alternately wetting and drying mortars containing calcium stearate, the amount of such being 2 per cent of the total weight of cementing materials

[Tests begun when specimens were 48 hours old. (Average values for 6 specimens; + denotes expansion, - denotes shrinkage.)]

\begin{tabular}{|c|c|c|c|c|c|c|}
\hline Cementing material & $\begin{array}{l}\text { Proportions by } \\
\text { volume }\end{array}$ & $\begin{array}{l}3 \text { months } \\
\text { in water }\end{array}$ & $\begin{array}{l}\text { Dried to } \\
\text { "constant } \\
\text { length" }\end{array}$ & $\begin{array}{l}3 \text { months } \\
\text { in water }\end{array}$ & $\begin{array}{l}\text { Dried to } \\
\text { "constant } \\
\text { length" }\end{array}$ & $\begin{array}{l}\text { Maxi- } \\
\text { mum de- } \\
\text { viation } \\
\text { from any } \\
\text { average } \\
\text { value }\end{array}$ \\
\hline $\begin{array}{l}\text { Portland cement No. } 1 \\
\text { Masonry cement No. } 10 \\
\text { Portland cement No. } 1\end{array}$ & $\begin{array}{l}1 \mathrm{PC}: 3 \mathrm{~S}_{-} \\
1 \mathrm{MC}: 3 \mathrm{~S} . \ldots \\
1 \mathrm{PC}: 4 \mathrm{~S}\end{array}$ & $\begin{array}{l}\text { Per cent } \\
+0.012 \\
+.024 \\
+.007\end{array}$ & $\begin{array}{r}\text { Per cent } \\
-0.081 \\
-.168 \\
-.074\end{array}$ & $\begin{array}{l}\text { Per cent } \\
+0.054 \\
+.084 \\
+.041\end{array}$ & $\begin{array}{r}\text { Per cent } \\
-0.053 \\
-.072 \\
-.045\end{array}$ & $\begin{array}{r}\text { Per cent } \\
9 \\
7 \\
6\end{array}$ \\
\hline $\begin{array}{l}\text { Lime No. 6; Portland cement } \\
\text { No. } 1 \\
\text { Do }\end{array}$ & $\begin{array}{l}\text { 1L:1PC:6S } \\
1 \mathrm{~L}: 1 \mathrm{PC}: 8 \mathrm{~S}\end{array}$ & $\begin{array}{r}+.010 \\
+.006\end{array}$ & $\begin{array}{l}-.116 \\
-.065\end{array}$ & $\begin{array}{l}+.053 \\
+.010\end{array}$ & $\begin{array}{l}-.040 \\
-.048\end{array}$ & $\frac{12}{5}$ \\
\hline
\end{tabular}


In Table 8 are given the average percentage linear expansions of certain mortars, with and without calcium stearate, during the first 24 hours in water following the first oven drying.

TABLE 8.-Linear expansion during the first 24 hours in water following the first oven drying and when specimens were approximately 4 months old

[A verage values for 6 specimens]

\begin{tabular}{|c|c|c|c|c|}
\hline \multirow{2}{*}{ Cementing materials } & \multirow{2}{*}{$\begin{array}{l}\text { Proportions by } \\
\text { volume }\end{array}$} & \multicolumn{2}{|c|}{ Linear expansion } & \multirow{2}{*}{$\begin{array}{l}\text { Maxi- } \\
\text { mum } \\
\text { deviation } \\
\text { from any } \\
\text { average } \\
\text { value }\end{array}$} \\
\hline & & $\begin{array}{l}\text { With } \\
\text { calcium } \\
\text { stearate }\end{array}$ & $\begin{array}{l}\text { Without } \\
\text { calcium } \\
\text { stearate }\end{array}$ & \\
\hline $\begin{array}{l}\text { Portland cement No. } \\
\text { Masonry cement No. } 10 \\
\text { Portland cement No. } 1 \\
\text { Lime No. 6; Portland cement No.1 } \\
\text { Do. }\end{array}$ & $\begin{array}{l}\text { 1PC:3S } \\
\text { 1MC:3S } \\
\text { 1PC:4S } \\
1 \mathrm{~L}: 1 \mathrm{PC}: 6 \mathrm{~S}^{\mathrm{N}} \\
1 \mathrm{~L}: 1 \mathrm{PC}: 8 \mathrm{~S}\end{array}$ & $\begin{array}{r}\text { Per cent } \\
0.006 \\
.024 \\
.009 \\
.018 \\
.006\end{array}$ & $\begin{array}{r}\text { Per cent } \\
0.019 \\
.043 \\
.014 \\
.022 \\
.013\end{array}$ & $\begin{array}{r}\text { Per cent } \\
20 \\
35 \\
36 \\
40 \\
24\end{array}$ \\
\hline
\end{tabular}

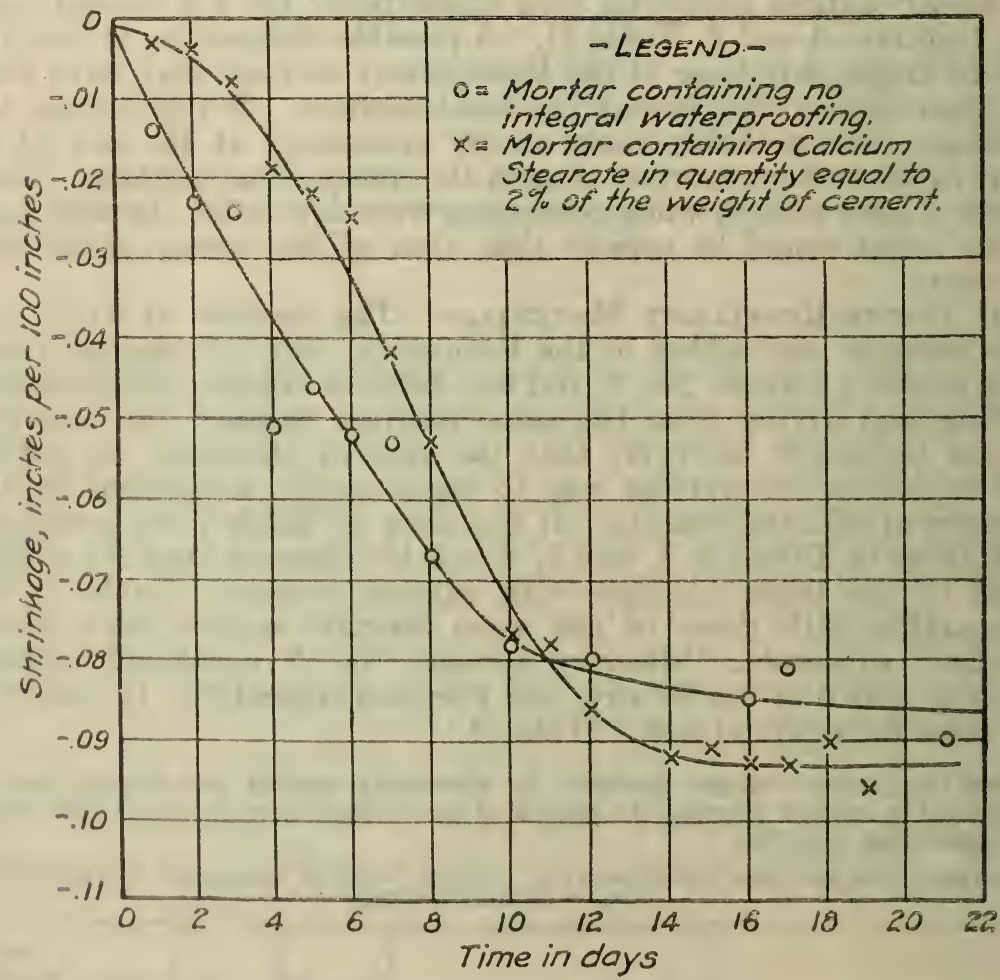

FIGURE 6.-The effect of calcium stearate on the rate of shrinkage (on drying) of hardened mortars

Figure 6 illustrates the shrinkage of $1: 3$ mortar specimens with and without calcium stearate. The curve for the mortar containing calcium stearate was obtained by plotting the average linear shrinkages from day to day of the six 1:3 specimens made with masonry cement No. 2. The other curve is descriptive of the average rate of shrinkage of the six 1:3 specimens made with Portland cement No. 11 . 
The data plotted in Figure 6 were obtained from strain-gage readings taken when the specimens of both mortars were being dried simultaneously at $38^{\circ} \mathrm{C}$. in the oven, subsequent to drying for four days in the laboratory. "The "zero" mark in the ordinate scale is the reading taken on the day the specimens were put in the oven. During the four days' drying in the laboratory there was a very small amount of shrinkage in all of the specimens. The rate of shrinkage was most rapid when the bulk of the water was removed. According to curves presented by Allan ${ }^{11}$ the rate of shrinkage in concrete units does not become very noticeable until from 70 to 80 per cent of the moisture is lost.

It is indicated from the plotted data of Figure 6 and the tabulated data of Table 8 that the rate of linear change was diminished by the presence of calcium stearate. However, upon continued wetting or drying, the presence of the stearate had no noticeable effect on the final values obtained.

\section{BRICK}

\section{(a) EFFECT OF THERMAL CHANGE}

The term "soft" has but little meaning when applied to materials, such as brick Nos. $2,3,4,5$, and 6 of Table 1 . It is noted that the absorption ranges were limited in these cases. Also, strictly speaking, there were no individual bricks among the other numbers $(1,7$, and 8 ) which could have been properly called hard burned. Among each make of brick, some samples were harder burned than others. The terms, "hard" and "soft" burned in this connection are merely relative.

The linear thermal coefficients of the relatively hard and soft burned brick of each of the eight types are given in Table 9 . The lowest coefficient in this table is $0.36 \times 10^{-5}$ and the highest is $0.85 \times 10^{-5}$ per degree centigrade. The lowest values were obtained with brick Nos. 5 and 6 , both made from fire clay. The highest thermal coefficients were had by brick Nos. 7 and 8, the most porous of all of the eight types of brick. With the exception of brick Nos. 7 and 8 , the linear thermal coefficients of the eight makes of brick were distinctly lower than values for the 1:3 mortars, given in Figure 3.

TABLE 9.-Linear thermal coefficients of expansion of brick Coefficient, $C=\frac{\Delta L}{L \Delta t}$ where $\Delta L$ is the change in length per 20 inches during a temperature $\Delta \ell^{\circ} \mathrm{C}$.

[Values are arerages for 2 specimens of 3 bricks each]

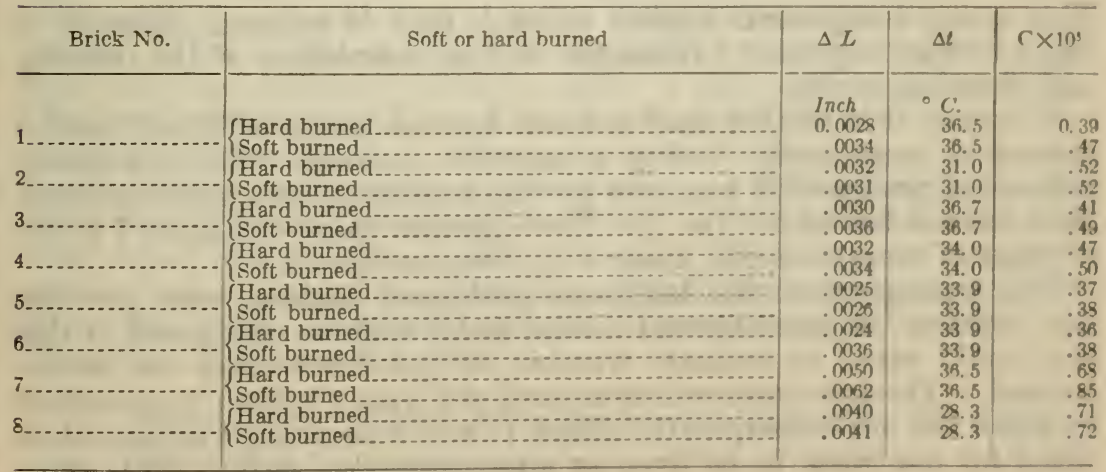

11 W. D. M. Allan, Shrinkage Measurements of Concrete Masonry, Proc. Am. Concrete Inst., 26, 6. p. $699 ; 1930$. 
The average linear thermal expansion of $1: 3$ mortars made with masonry cement No. 5 was 0.0068 inch per 20 inches per $36^{\circ} \mathrm{C}$. Brick No. 1 (hard burned) expanded 0.0028 inch per 20 inches when the temperature increased $36^{\circ} \mathrm{C}$. The differential expansion between those two materials for this temperature change is computed as 0.004 inch per 20 inches.

\section{(b) ALTERNATE WETTING AND DRYING}

The expansion of the brick specimens during one month's immersion in water is designated as $A$ in Figure 7 . The shaded columns denote expansions of the relatively hard burned and the unshaded columns denote expansion of the relatively soft-burned bricks of each make.

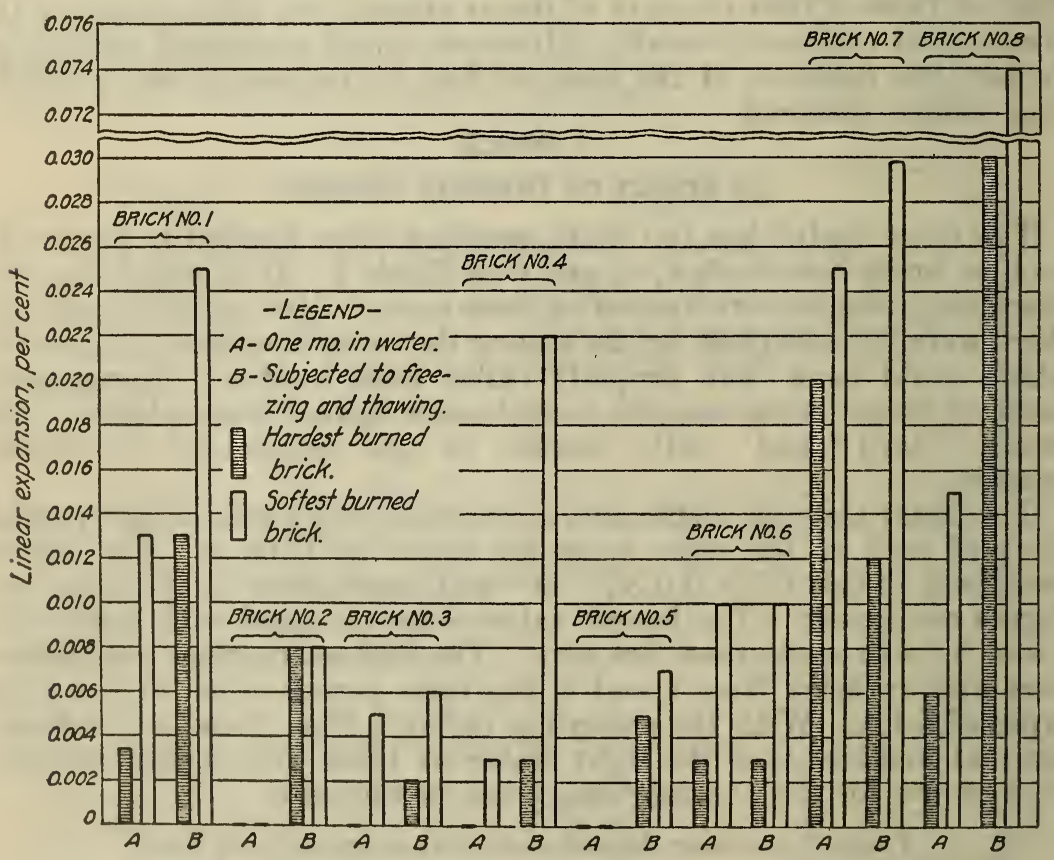

FIGURE 7.-Linear expansions of brick specimens during wetting $(A)$ and alternately freezing and thawing $(B)$

This same designation applies to each pair of columns marked $B$ (fig. 7) which represent expansions at the completion of the freezing and thawing cycles.

It is seen that neither hard nor soft-burned bricks of types 2 and 5 expanded measurably during a month's soaking. The maximum expansion produced in any case by this treatment was 0.025 per cent (soft-burned bricks of type 7). Each plotted value of Figure 7 is the average of measurements made with two specimens.

The expansions of the bricks on prolonged soaking were greatest for "salmon" or underburned bricks, and it may be that a test of this sort could serve to indicate whether or not bricks may be underburned. The specimens which expanded during a month's inmersion in water did not subsequently shrink to any measureable extent when dried for one week in an oven at approximately $150^{\circ} \mathrm{C}$. This same 
condition existed when specimens which had expanded during freezing and thawing were subsequently dried in this manner. Holscher ${ }^{12}$ reports similar expansions in clay bodies during autoclave treatment.

(c) ALTERNATE FREEZING AND THAWING

The average expansion (for two specimens of three bricks each) at the completion of the freezing and thawing tests aro marked $B$ in Figure 7. When no disintegration occurred the specimens wero subjected to from 18 to 20 cycles of freezing and thawing. Softburned bricks of type 7 were subjected to 10 cycles; soft-burned bricks of type 8,2 cycles; and hard-burned bricks of type 8,5 cycles.

It is conceivable that both brick and mortar in a masonry wall may at times become saturated with water. It is not so likely,

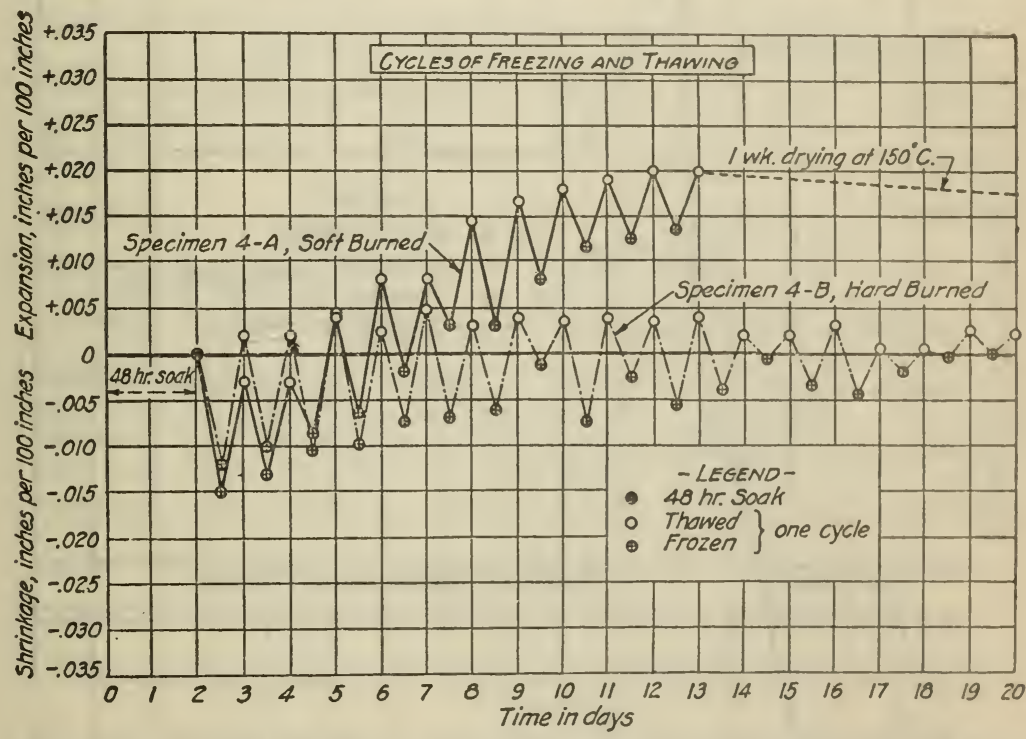

F'IGORE 8.- Linear expansion and contraction of saturated brick specimens (bricks of type 4) during alternate freezing and thawing

The effect of moisture was greater that than of temperature changes in the case of soft-burned bricks.

however, that this moisture, saturating these materials, would be alternately frozen and thawed many times without any drying taking place. When brick are kept well saturated during freezing and thawing tests, the apparent porosity tends to increase a small nmount. ${ }^{13}$ There is a progressive increase in the extent of saturation of the brick under these conditions. After many cycles of freezing and thawing, brick contain very nearly as much water as they normally contain when kept in boiling water for five hours. It is reasonable to suppose that when there is but little pore space not filled with water the pressure produced by the water changing to ice tends to increase the size of the pore. Evidently this small distension is permanent under all normal climatic conditions.

12 H. H. Holscher, Effects of Autoclave Treatments on Ceramic Bodies and Clays, J. Am. Ceram. Soc.,

14, 3, pp. 207-218; 1931.
13 L. A. Palmer and J. V. Hall, Some Results of Freozing and Thawing Tests Made with Clay and Shale Brick, Proc. Am. Soc. Test. Materials, 30, p. 767 . 
This slight increase in apparent porosity during progressive freezing and thawing is attended by a small and relatively slow (usually) expansion of the brick. This is illustrated in Figure 8 . If the brick are not burned to the proper maturing temperature, the expansion (as well as disintegration) is rapid. The softer burned bricks of type 8 (fig. 9) began to disintegrate after the first two cycles. The graphs (figs. 8, 9, and 10), represent all of the extreme and intermediate conditions that were obtained. The specimens containing the

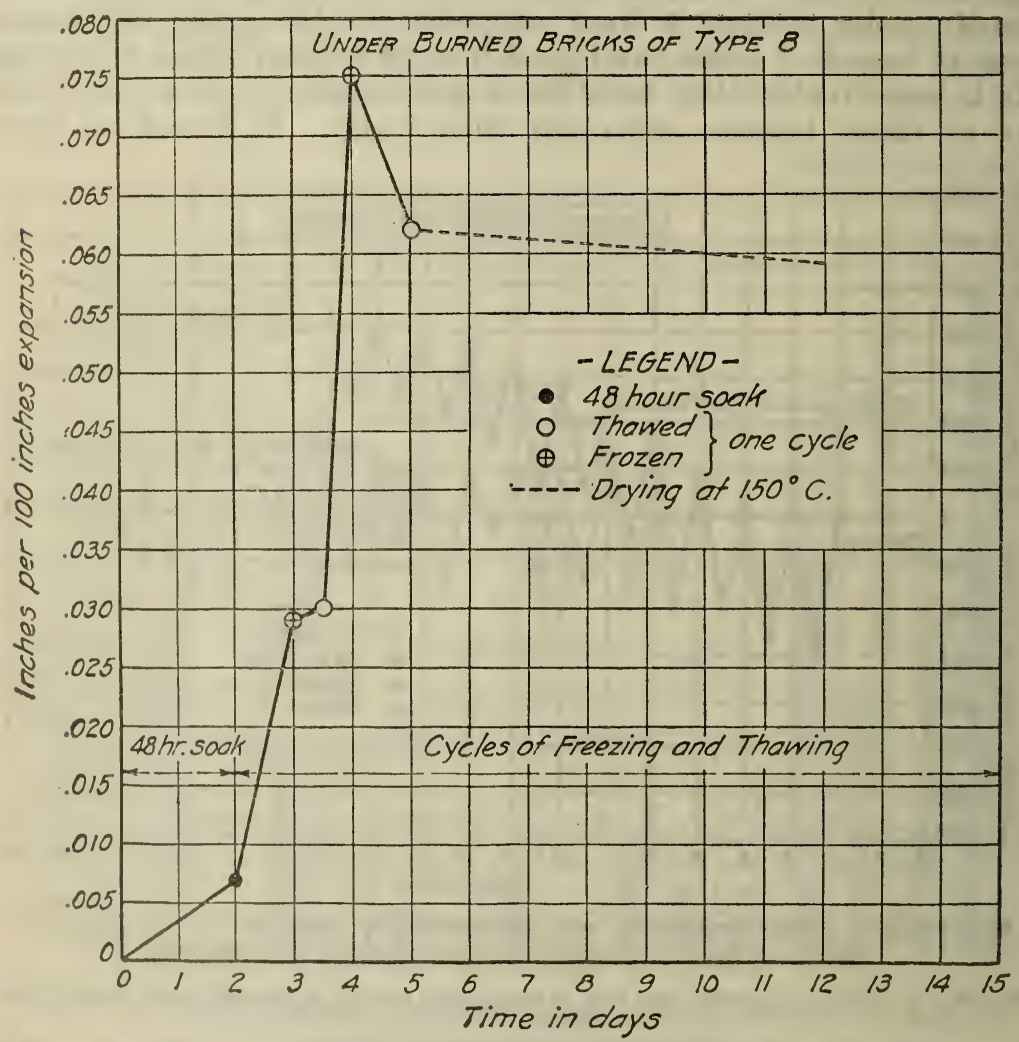

FIGURE 9.-Rapid cxpansion of saturated underburned bricks during alternate freezing and thawing

harder bricks of type 8 were very similar in their behavior during freezing and thawing to the specimens of soft-burned bricks of type 7, shown in Figure 10. The graphs of the plotted data (not given) obtained with specimens of both hard and soft-burned bricks of types 2, 3, 5, and 6 and with hard-burned bricks of type 1 are very similar to the hard-burned brick of type 4. (Fig. 8.) The terms, "underburned" and "salmon" as applied to these brick are those used by the manufacturer. They were admittedly unfit for facing purposes and were "draw trials" submitted for experimental tests. 


\section{SUMMARY AND CONCLUSIONS}

1. The data indicate that it is possible that differential volume changes may occur between the brick and mortar. A change in temperature alone may cause this. It is indicated, however, that under average climatic conditions, temperature variations would not have so great an effect as variation in the moisture content of the materials.

2. Among the various mortars studied, those which underwent the smallest volume changes during alternate wetting or drying subsequent to hardening, contained only lime and sand.

3 . The extent of shrinkage and expansion produced by varying the moisture content was much less in hard-burned (or well-burned)

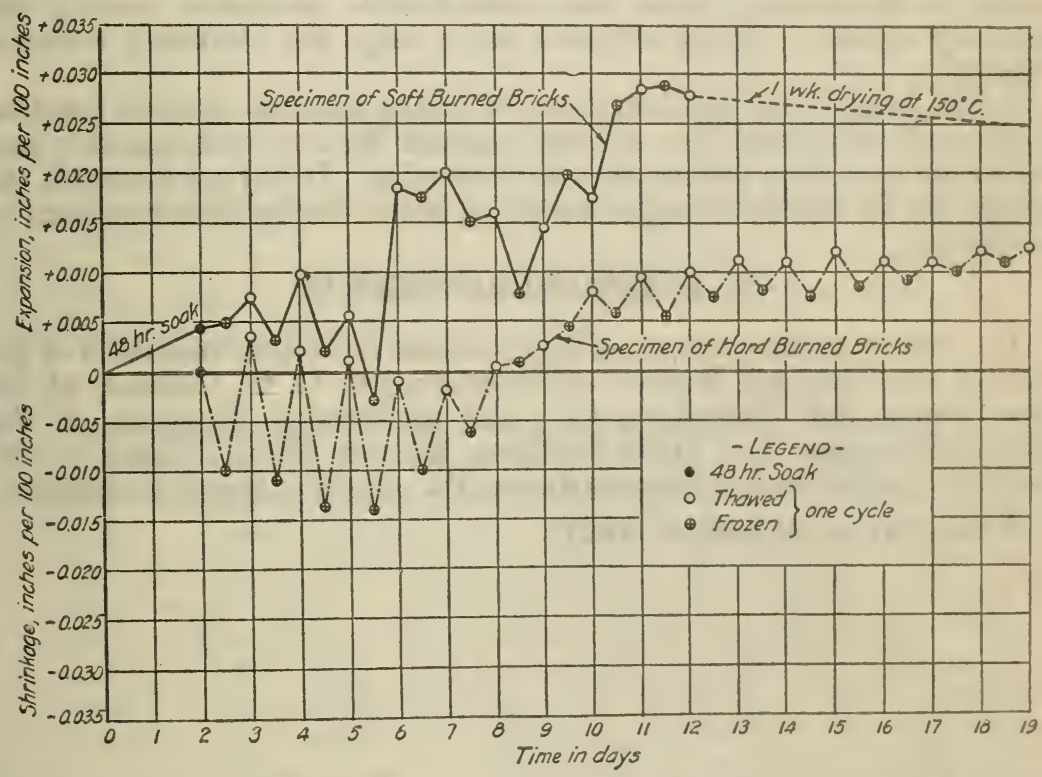

FiguRE 10.-Linear changes produced by alternately freezing and thawing hard and soft burned bricks (type 7) made from the same clay and molded by the same process

bricks than in any of the masonry and Portland cement mortars. The difference between lime mortars and bricks is not so great.

4. From the standpoint of volume changes subsequent to hardening, there is less differential volume change if the mortar consists solely of lime and sand. This statement does not apply to masonry containing underburned bricks.

5. It is hardly worth while to use a $1: 4$ in preference to a $1: 3$ mortar in brick masonry construction if the shrinkage and expansion alone are considered.

6 . The volume changes subsequent to hardening were less in mortar made from 2 volumes of lime to 1 volume of Portland cement to 9 volumes of sand than in mortar made from 1 volume of Portland cement to 3 volumes of sand, using the same cement and sand in both mortars. The data further indicate that from the standpoint of volume changes, there is no distinct advantage in a 1 lime: 1 Portland 
cement: 6 sand mortar, using the cements and limes described in this investigation.

7. The initial shrinkage of the lime mortars was greater, in all but one case, than that of the various cement mortars. The exception was masonry cement No. 9. It is believed that the shrinkage of mortars occurring during hardening would be less destructive in masonry than subsequent volume changes, even though the latter are much smaller in magnitude than the former. The possibility of any separation of the unit from the mortar during initial shrinkage would depend on the rate and magnitude of such shrinkage and also on the rate of hardening of the mortar.

8 . From the standpoint of volume changes both during and subsequent to hardening, there was considerable variation among the masonry cements, which differed more than the Portland cements studied.

9. The presence of calcium stearate in the mortars studied resulted apparently in diminishing to some extent the rate of expansion and shrinkage occurring subsequent to hardening. It did not diminish the magnitude of volume changes occurring either during or subsequent to hardening.

\section{ACKNOWLEDGMENTS}

The author wishes to express his gratitude to various members of the staff of the National Bureau of Standards; to C. C. Connor, of the New Jersey Bell Telephone Co.; and to Stanley Newman, of the Stanley Newman Co., Little Building, Boston, Mass. These gentlemen gave advice and assistance during the course of this investigation.

Washington, March 21, 1931. 